\title{
Oxygen, carbon, and nutrients in the oligotrophic eastern subtropical North Atlantic
}

\author{
P. Kähler, A. Oschlies, H. Dietze, and W. Koeve \\ IFM-GEOMAR, Leibniz-Institut für Meereskunde, Düsternbrooker Weg 20, 24105 Kiel, Germany
}

Received: 6 August 2009 - Published in Biogeosciences Discuss.: 9 September 2009

Revised: 11 March 2010 - Accepted: 22 March 2010 - Published: 26 March 2010

\begin{abstract}
The Beta Triangle, a region of the oligotrophic subtropical eastern North Atlantic Ocean, is notorious for its enigmatic oxygen, carbon, and nitrogen balances, in which nutrient supply is said to explain only a fraction of production necessary for estimated carbon export. Rates of dissolved organic carbon accumulation and dissolved organic nitrogen utilization in surface water and an assessment of oxygen utilized, organic matter consumed, and nitrate and phosphate regenerated in subsurface water, show that conventional production estimates miss substantial shares of biotic production.

The shallow export of total organic carbon, predominantly dissolved (DOC), by subduction is responsible for about 50$70 \%$ of apparent oxygen utilization in subsurface water between the base of the surface layer at ca. $140 \mathrm{~m}$ and ca. $195 \mathrm{~m}$ depth, but it is insignificant below. Additionally, there is an estimated accumulation of 1.0 to $1.75 \mathrm{molDOC} \mathrm{m}^{-2} \mathrm{a}^{-1}$ in surface water. Including DOC dynamics in its carbon balance reveals the surface of this ultra-oligotrophic part of the ocean to be net autotrophic.

Increasing subsurface values of excess nitrogen (DINxs) imply the export of nitrogen from surface water stemming from production not exclusively fuelled by new nitrate supplied from below. Total organic nitrogen (almost exclusively dissolved, DON) is consumed in the surface layer at a rate estimated at 0.13 to $0.23 \mathrm{~mol} \mathrm{~m}^{-2} \mathrm{a}^{-1}$. There is no variation in dissolved organic phosphorus (DOP) in the same direction. DON utilization thus contributes to the pronounced subsurface DINxs signature.

DOC export and accumulation are important in the carbon balance in surface and near-surface water. DON utilization and, probably, $\mathrm{N}_{2}$ fixation contribute significant amounts to
\end{abstract}

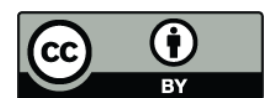

Correspondence to: $\mathrm{P}$. Kähler

(pkaehler@ifm-geomar.de) the nitrogen supply of surface water. These processes can close part of the enigmatic carbon and nitrogen balances in the Beta Triangle. There are, however, no comparable processes which can explain the equally enigmatic situation concerning phosphorus supply in this area.

\section{Introduction}

\subsection{The problem}

The biotic contribution to the air-sea flux of carbon dioxide in the oligotrophic subtropical gyres of the oceans has been discussed controversially regarding its magnitude and even its direction (del Giorgio et al., 1997; Williams, 1998; Serret et al., 2001, 2009; del Giorgio and Duarte, 2002; LopezUrrutia et al., 2006; Riser and Johnson, 2008; a short history of the ensuing controversy is given by Williams et al., 2004). These regions have been described to be heterotrophic, i.e. more organic carbon is thought to be consumed there than produced - even within the productive surface layer, the euphotic zone. Assuming this layer to be in contact with the atmosphere (an assumption valid generally, but not everywhere; Oschlies and Kähler, 2004), this would imply that biota add $\mathrm{CO}_{2}$ to surface water contributing to a source of $\mathrm{CO}_{2}$ to the atmosphere in the oligotrophic regions of the subtropical oceans. While in the discussion about the heterotrophy of the oligotrophic parts of the ocean the question of $\mathrm{CO}_{2}$ flux was not addressed directly, it is straightforward to imply that heterotrophy contributes to locally adding $\mathrm{CO}_{2}$ to the atmosphere, an effect not negligible considering the large area such regions cover in the ocean. The notion of the oligotrophic ocean to be heterotrophic is not supported by all approaches though. Experimental and in-situ geochemical evidence can often not be reconciled.

Published by Copernicus Publications on behalf of the European Geosciences Union. 
There is the case of primary production measurements (Steemann-Nielsen, 1952), for example. One of their shortcomings is that they have been introduced as measurements of particulate-matter production and as a rule been carried out as such (Parsons et al., 1984), i.e. neglecting the production of dissolved organic carbon (DOC). It has become known, however, that the net accumulation of DOC in surface water (Peltzer and Hayward, 1996; Hansell, 2002; Kähler and Koeve, 2001) as well as its export can be important (Doval and Hansell, 2000) in regional carbon balances. While standard primary-production measurements record the uptake of ${ }^{14} \mathrm{C}$ into particulate matter only, the standard organic-matter consumption measurement by oxygen consumption record the reaction of particulate and dissolved matter. Therefore, balances of production and respiration which use Steemann-Nielsen production and oxygen consumption measurements are intrinsically biased towards heterotrophy. In principle, the alternative experimental determination of net production from oxygen change in incubation bottles (Gaarder and Gran, 1927) is flawless in this respect, but, oddly, it is also with this method that oligotrophic oceanic systems have been described as (albeit slightly) heterotrophic (Williams et al., 2004; Duarte et al., 1999) while in the same places, in-situ oxygen measurements and other data suggest autotrophy (Karl et al., 2003; Riser and Johnson, 2008).

A different way of estimating rates of reaction in the ocean is from differences in the stocks of nutrients, oxygen, and organic matter in the direction of water transport combined with water transport rates. The differences in stocks of reactants or products (forming gradients) are ascribed to the production-related processes of nutrient consumption or regeneration and the build-up or breakdown of organic matter, the latter coupled with oxygen consumption. This is possible where the mixing of water masses of different preformed values is absent or negligible, and, in the case of oxygen, air-sea exchange is absent (as it is in subsurface water). If water transport rates along the gradients are known, production and consumption rates of any substance can be calculated as the product of its concentration gradient and the bulk transport rate of water. Thus determined, production or consumption rates are free from incubation artefacts and certain methodological shortcomings. They are representative of larger scales of time (months to decades) and space (hundreds of kilometres) than those from local incubations, which are typically conducted for hours to a day on a few days at selected locations. On such large scales of space and time, even extremely small rates of reaction can be perceived, when differences formed over months or years rather than hours are analysed. The estimates are, however, subject to errors in the physical transport-rate estimates of water. Furthermore they rely on the assumption of steady state; i.e. observed gradients and water transport rates are considered to be constant and permanent.
In the "Beta Triangle", a region of the oligotrophic subtropical eastern North Atlantic (Fig. 1), such analyses of oxygen utilization rates in subsurface water imply a high rate of organic matter decomposition which, as it is considered to be based on organic matter exported vertically from surface water, would mean that the "surface fixation of carbon ... is many times greater than deduced from ${ }^{14} \mathrm{C}$ assimilation techniques" (Jenkins, 1982). The postulated high export from the surface thought to fuel this high subsurface oxygen utilization corresponds to either a large - and yet unexplained - autotrophic component in the surface layer or another organic matter source there, equally not identified.

In oceanic organic-matter budgeting, yet another common method to estimate net production (which in the long run is equalized with new production; Williams, 1993) is from nitrate consumption in, or nitrate supply to, surface water (Eppley and Petersen, 1979) - a simplified adaption of the new production concept of Dugdale and Goering (1967). To transform nitrogen units into carbon units, the Redfield ratio (moles $\mathrm{C}: \mathrm{N}: \mathrm{P}=106: 16: 1$; Redfield et al., 1963) is widely used. The molar oxygen demand for such organic matter to be completely oxydized (with $\mathrm{CO}_{2}$ and $\mathrm{NO}_{3}$ among the products of remineralization) is $138 \mathrm{~mol} \mathrm{O}_{2}$. Hence the complete Redfield ratio of $\mathrm{O}_{2}: \mathrm{C}: \mathrm{N}: \mathrm{P}=138: 106: 16: 1$. Modifications to it suggested e.g. by Takahashi et al. (1985), Minster and Boulahdid (1987), Andersen and Sarmiento (1994) and Körzinger et al. (2001), account for differences observed in different ocean basins and the fact that the oxidation state of carbon in organic mater is not exactly that of carbohydrates and more oxygen is needed for its oxidation to $\mathrm{CO}_{2}$. Their ratios differ from the Redfield ratio, but not to an extent to substantially alter our conclusions. It is the $\mathrm{O}_{2}: \mathrm{C}$ ratio suggested by Anderson (1995) of 150:106 which we will use in the following.

Budgets of $\mathrm{C}$ and $\mathrm{N}$ composed using the simplified new production concept and the Redfield ratio are also not always consistent. In the Beta Triangle region it is not only primary production as commonly measured, but also nitrate supply to the surface, which falls short of the needs of a production necessary to fuel deep oxygen utilization. The oxygen utilization rate (OUR) of $5.7 \mathrm{~mol} \mathrm{O}_{2}$ per square metre and year (Jenkins, 1982) implies a net production equivalent of $0.61 \mathrm{~mol} \mathrm{~m}^{-2} \mathrm{a}^{-1}$ nitrogen utilization, whereas vertical diffusive nitrate supply, at that time considered the only important source of $\mathrm{N}$ to the surface in the open ocean, was estimated at $0.05 \mathrm{~mol} \mathrm{~N} \mathrm{~m}^{-2} \mathrm{a}^{-1}$ by Lewis et al. (1986), a rate recently reproduced in its magnitude in an eddy-resolving model by Oschlies (2002a).

This leaves an unexplained deficit of $0.56 \mathrm{~mol} \mathrm{~N} \mathrm{~m}^{-2} \mathrm{a}^{-1}$ (about ninety percent) when applying the concept of new and export production with nitrate as the only nitrogen source and all participating elements in the Redfield ratio (in the following referred to as "the conventional concept"). Alternatively, an oxygen consumption of about $5.2 \mathrm{~mol} \mathrm{O}_{2} \mathrm{~m}^{-2} \mathrm{a}^{-1}$ independent of nitrate utilization would need to be explained. 


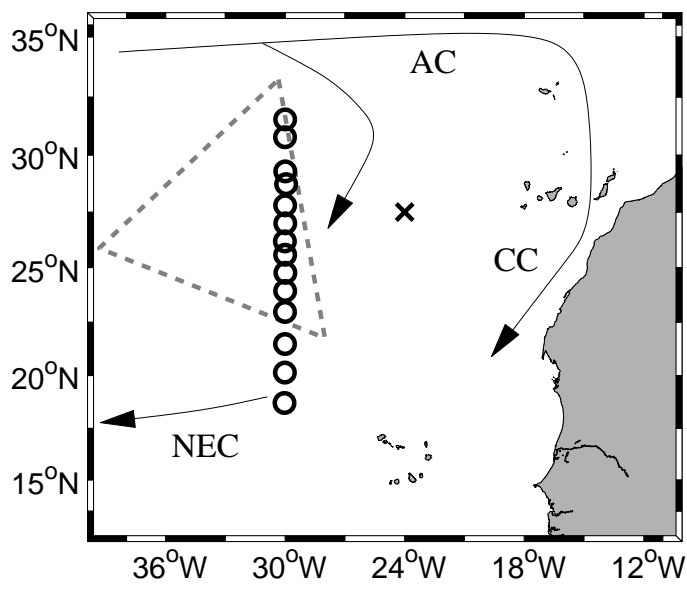

Fig. 1. Cruise track with stations (o). The triangle is the Beta Triangle of Jenkins (1982, 1987), x marks the location of Lewis' (1983) estimate of diffusive nitrate supply. Arrows sketch the pathway of surface currents: Azores Current (AC), Canary Current (CC) and North Equatorial Current (NEC).

Such inconsistency of the conventional concept, i.e. a mismatch between organic matter production in the Redfield ratio and nitrate supply, is a general, and as yet unexplained, problem in the oligotrophic subtropical gyres (Mann and Lazier, 1991; Sarmiento and Gruber, 2006). In the western North Atlantic Ocean similar findings led to what became known as the "Bermuda Paradox", where organic matter production implied from $\mathrm{CO}_{2}$ drawdown continues without observed nutrient consumption, of which Michaels et al. (1994) and Lipschultz et al. (2002) give accounts. Mouriño-Carballido and Neuer (2008) describe the carbonnitrogen mismatch described in the North Atlantic subtropical gyre as the "conundrum of missing nutrients" and "the conundrum of missing organic carbon".

\subsection{Possible solutions}

There is an ongoing discussion about eddies being able to effectively inject nitrate into surface surface water in addition to diffusive supply. Jenkins and Wallace (1992) and McGuillicuddy et al. (1998) argued that the upward displacement of isopycnals and nutriclines associated with eddies might effectively lift nitrate to the surface, potentially adding extra nutrients. A model study by Oschlies (2002b) refuted this idea (basically because any extra nutrient input by eddies is at the expense of other nutrient-adding mechanisms) and constrained the additional nitrate supply to the surface induced by eddies to less than $0.05 \mathrm{~mol} \mathrm{~m}^{-2} \mathrm{a}^{-1}$. Recent observations in a mode-water eddy showing a massive supply of nutrients to the surface driven by eddy/wind interaction (McGillicuddy et al., 2007; Ledwell et al. 2008) revived the discussion since earlier model studies had not included this particular mechanism. A model study by Eden and Dietze (2009), including an explicit representation of eddy/wind interaction confirmed the low estimate of Oschlies (2002b), however.

Also, diffusive nitrate supply to the surface may itself have been underestimated by state-of-the-art methods. Accounting for double diffusion (as suggested by Hamilton et al., 1989), vertical diffusive nitrate input was adjusted upward by a factor of two to $0.1 \mathrm{~mol} \mathrm{~m}^{-2} \mathrm{a}^{-1}$ by Dietze et al. (2004) compared to previous estimates (Lewis et al., 1986; Oschlies, 2002a). Adding up the combined effect of physical transport mechanisms into the nutrient-consuming surface layer (which include the net effect of eddy pumping, internal-wave induced diffusion and double diffusion, and, finally, net surface advection) yielded a net nitrate input into the surface layer of the study area of $0.15 \mathrm{~mol} \mathrm{~N} \mathrm{~m}^{-2} \mathrm{a}^{-1}$ (Dietze et al., 2004). This is still far from the $0.61 \mathrm{~mol} \mathrm{~N} \mathrm{~m}^{-2} \mathrm{a}^{-1}$ conjectured as needed to satisfy the nitrogen demand calculated from the subsurface oxygen utilization rate (OUR).

The term carbon overconsumption has been coined for carbon uptake higher than the Redfield-ratio equivalent of consumed nitrate (Sambrotto et al., 1993; Toggweiler, 1993). It affects regional budgets of carbon and nitrate in surface water only if the excess carbon fixed is stored or exported. The accumulation, and export of dissolved organic matter of a large $\mathrm{C}: \mathrm{N}$ ratio can explain carbon overconsumption as shown by Kähler and Koeve (2001) and Körzinger et al. (2001) for the temperate eastern North Atlantic, but to a considerably smaller extent than suggested for that area by Sambrotto et al. (1993). In these studies, excess carbon showed to be fixed during summer, a season of nutrient depletion and high temperature in surface water, i.e. when conditions were similar to those of the oligotrophic subtropics. Koeve (2004, 2005) showed again that carbon overconsumption in the temperate eastern North Atlantic is considerably lower than described by Sambrotto et al. (1993) and not associated with the spring bloom, but with a season of nutrient depletion.

A large C:N ratio may be the result of a small amount of nitrogen rather than a large one of $\mathrm{C}$. Thus, should there be sources of nitrogen utilized for production in addition to the nitrate considered, the $\mathrm{C}: \mathrm{NO}_{3}$ ratio would likewise be high. Note that the utilization of unaccounted-for nitrogen cannot be distinguished from carbon overconsumption as it was described by Sambrotto et al. (1993). A DIC: $\mathrm{NO}_{3}$ ratio indicating carbon overconsumption may thus in fact point to the neglect of nitrogen sources for new production. Taking nitrate for total new nitrogen excludes nitrogen sources such as dissolved organic nitrogen (DON) and $\mathrm{N}$ from nitrogen fixation and atmospheric sources.

In this study we investigate possible solutions to the carbon-nitrogen mismatch of the conventional concept in the Beta Triangle region. Total organic matter, nutrient, and oxygen analyses were performed to study excess carbon from, and additional nitrogen sources for, organic matter production. We estimate two rates which are not included in the conventional concept: the accumulation of DOC and the utilization of DON in surface water. We also assess the importance 
of DOM export for subsurface oxygen utilization as well as phosphorus, nitrogen, and excess nitrogen regeneration. The latter was suggested as a proxy of nitrogen fixation by Michaels et al. (1996) and Gruber and Sarmiento (1997). We evaluate the possibilities and limitations of this concept for the study area. Where possible (i.e. in subsurface water) we compare our results with those of Jenkins $(1982,1987)$, because his work opened the still ensuing controversy about the carbon (or the trophic) and nutrient balances of the oligotrophic subtropical ocean.

\section{Methods}

Data for this study were obtained during two cruises into the subtropical North Atlantic, conducted aboard the FS Poseidon. The first cruise took place between 14 April and 4 May 2001. A second cruise took place from 10-22 March 2002. This cruise track and stations are shown in Fig. 1.

Nutrients (nitrate, nitrite, phosphate, silicate) were measured following standard protocols as described by Grasshoff et al. (1983) using an autoanalyzer, total dissolved P photometrically after persulfate digestion, TOC and TDN by hightemperature oxidation as described by Kähler et al. (1997). POC and PON were recovered with GF/F filters and measured by $\mathrm{C} / \mathrm{N}$ analyzer (Heraeus Elemental Analyser, Elementar, Hanau, Germany; Ehrhardt and Koeve, 1999), POP by phosphate analysis after persulfate digestion of particles collected on GF/F filters (Grasshoff et al., 1983). Oxygen measurements were by Winkler titration with optical endpoint determination (SIS Sensoren Instrumente GmbH, Schwentinental, Germany; Grasshoff et al., 1983). The WOCE standard was met (SIS Instruments manual).

Combining water transport rates and gradients in stocks, rates of reaction can be calculated. Three transport modes must be considered for a complete balance: firstly, subsurface water transport rates of subducted water were used to estimate the decomposition of organic matter from the gradient of AOU and apparent water age (giving the oxygen utilization rate, OUR) by Jenkins $(1982,1987)$. We did not measure any proxy to calculate the time component in this depth range, and we can therefore only compare states (rather than rates) between his work and ours. We interpolate the properties measured by us in the same density intervals for which Jenkins (1987) reported his oxygen utilization rates to ensure consistency with his work. In this way our results are comparable with those of Jenkins $(1982,1987)$ and well suited to address the questions raised there.

Secondly, surface current velocity combined with changes in stocks in the direction of the current were used to estimate the rates of TOC accumulation and TON consumption in surface water. It was measured continuously with a VM-ADCP (Dietze et al., 2004). The third transport rate of importance, vertical (diffusive) exchange along the transect studied by us, is the subject of Dietze et al. (2004), and diffusive fluxes given there are used here.

\section{Results}

\subsection{Subsurface water: oxygen, DOC, and nutrients; subduction and reaction}

A water mass analysis revealed a pronounced boundary between North Atlantic central water and South Atlantic central water at about $23^{\circ} \mathrm{N}$ (Dietze et al., 2004). Focusing on water masses of northern origin, isopycnal gradients are therefore determined only for the region north of this boundary, i.e. the southernmost data point we use is at $22.9^{\circ} \mathrm{N}$. This is essentially that part of our transect which is within the Beta Triangle (Fig. 1a). AOU and other properties analyzed along the 2002 Section are given in Figs. 2-6. In each case, the top panel gives a contour plot of the concentration of the respective substance or property. The five lower panels give the values interpolated onto five density levels and a linear regression through these between latitude $22.9^{\circ} \mathrm{N}$ and $31.6^{\circ} \mathrm{N}$ (or the northern outcrop around $27.5^{\circ} \mathrm{N}$ in case of the uppermost density level). We use the same density levels as Jenkins $(1982,1987)$ for in this part of our work we attempt to be as close as possible to his description. Table 1 lists the concentration gradients over distance (degrees latitude) obtained from the regressions.

A comparison of these gradients shows the relative importance of various processes on each isopycnal surface. Note that all waters of a particular density class are formed under similar conditions in the eastern North Atlantic and that transport along the section has a dominant southward component, any differences on each density level, given with respect to distance, represent different times since the time taken to cover the respective distances varies among the density intervals; the shallower the isopycnal, the faster is its southward water movement (Jenkins, 1987; his Table 3). We did not collect data allowing age determinations of the water in the presented transect. Rates of reaction are therefore not given here. Assuming a single end-member model, relative differences are independent of the time component, though, and since on any one density surface the same (unknown) time component applies, relative differences also represent relative rates.

General: In comparing the gradients with each other, we notice that the Redfield ratio $\left(\mathrm{O}_{2}: \mathrm{N}: \mathrm{P}\right)$ is not expressed on any density interval. For example, the value of $\mathrm{O}_{2}: \mathrm{NO}_{3}$ of 9.4 (=150:16) is exceeded near the surface (15.4) and much lower below (5.3 to 6.2). Since the Refield ratio has been used to deduce nitrogen regeneration from oxygen demand, the deviation may be taken as a first hint that the conventional concept, in which all reactants follow the Redfield ratio, is not suited to interpret our dataset. 
Table 1. Slopes of properties along $30^{\circ} \mathrm{W}$ between 22.9 and $32^{\circ} \mathrm{N}$ on isopycnal surfaces, and selected ratios.

\begin{tabular}{|c|c|c|c|c|c|c|c|c|c|c|}
\hline $\begin{array}{l}\sigma_{0} \\
\left(\mathrm{~kg} \mathrm{~m}^{-3}\right)\end{array}$ & $\begin{array}{c}\text { Mean depth } \\
\text { (m) }\end{array}$ & $\begin{array}{c}\frac{\Delta \mathrm{AOU}}{\left.\Delta \text { ( }^{\circ} \text { lat }\right)} \\
\left(\frac{\mathrm{mmol} \mathrm{m}^{-3}}{{ }^{\circ} \text { lat }}\right)\end{array}$ & 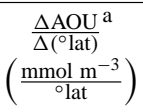 & $\begin{array}{c}\frac{\Delta \text { TOC }}{\left.\Delta \text { ( }^{\circ} \text { lat }\right)} \\
\left(\frac{\text { mmol m }^{-3}}{{ }^{\circ} \text { lat }}\right)\end{array}$ & $\begin{array}{c}\frac{\Delta \mathrm{NO}_{3}}{\left.\Delta \text { ( }^{\circ} \mathrm{lat}\right)} \\
\left(\frac{\mathrm{mmol} \mathrm{m}^{-3}}{{ }^{\circ} \text { lat }}\right)\end{array}$ & $\begin{array}{c}\frac{\Delta \mathrm{PO}_{4}}{\left.\Delta \text { ( }^{\circ} \text { lat }\right)} \\
\left(\frac{\mathrm{mmol} \mathrm{m}^{-3}}{{ }^{\circ} \text { lat }}\right)\end{array}$ & $\begin{array}{c}\frac{\Delta \text { DINxs }}{\Delta\left({ }^{\circ} \text { lat }\right)} \\
\left(\frac{\text { mmol m }^{-3}}{{ }^{\circ} \text { lat }}\right)\end{array}$ & $\frac{\Delta \mathrm{AOU}}{\Delta \mathrm{NO}_{3}}$ & $\frac{\Delta \mathrm{NO}_{3}}{\Delta \mathrm{PO}_{4}}$ & $\begin{array}{c}\frac{\Delta \mathrm{DINxs}}{\Delta \mathrm{NO}_{3}} \times 100 \\
(\%)\end{array}$ \\
\hline 26.2 & 140 & 4.3 & 1 & -3.0 & 0.28 & 0.013 & 0.076 & 15.4 & 21.5 & 27 \\
\hline 26.35 & 170 & 1.9 & 1.25 & -0.97 & 0.35 & 0.017 & 0.080 & 5.4 & 20.6 & 23 \\
\hline 26.5 & 220 & 2.0 & 3 & - & 0.35 & 0.019 & 0.040 & 5.7 & 18.4 & 11 \\
\hline 26.62 & 280 & 1.6 & 4.5 & - & 0.3 & 0.015 & 0.057 & 5.3 & 20.0 & 19 \\
\hline 26.85 & 395 & 1.8 & 5 & - & 0.29 & 0.011 & 0.11 & 6.2 & 26.4 & 38 \\
\hline
\end{tabular}

a from Jenkins (1987).

AOU (Fig. 2): We use our measurements of oxygen and calculated oxygen deficits to test whether the oxygen distribution as the basis of the oxygen utilization rates reported by Jenkins $(1982,1987)$ could be reproduced along the transect covered by us. AOU gradients read from the maps given by Jenkins (1987) along $30^{\circ} \mathrm{W}$ between 23 and $32^{\circ} \mathrm{N}$ are given for comparison in Table 1. The differences are considerable, indicating substantial variation which shows that the assumption of steady state is not justified. We observe higher AOU gradients on upper and lower ones on deeper isopycnals. There is agreement in overall magnitude though, i.e. high rates of oxygen consumption are implied also during our study. This indicates that the Beta Triangle's mismatch between OUR and nitrate supply described in the introduction should be a long-term feature, visible in our data.

TOC (Fig. 3): TOC decrease is significant only in the uppermost two isopycnals, i.e. in the density range of $\sigma_{0}=26.2$ and 26.35 , or down to about $195 \mathrm{~m}$ only. In these two layers 69 and $51 \%$ of the oxygen consumption can be ascribed to the breakdown of TOC (assuming the oxidation state of its carbon to be zero). The trends below, small decreases or even small increases, are insignificant. Particulate organic carbon displays a small gradient in the range concerned (data not shown), hence the TOC decrease is almost exclusively from dissolved organic carbon (DOC).

Nitrate (Fig. 4): The straightforward way to assess nitrogen remineralisation in subsurface waters is to analyse the nitrate increase along isopycnal surfaces in the same way as the increase in AOU. This would reveal the nitrogen requirements of exported production directly and without the need of assumptions about the $\mathrm{O}_{2}: \mathrm{N}$ stoichiometry as are necessary in the indirect calculation of nitrogen regeneration from oxygen changes. Our results are that nitrate increase is even higher when taken directly as opposed to nitrate calculated from AOU using the Redfield ratio because the $\mathrm{O}_{2}: \mathrm{N}$ ratios are much lower than 150:16 (=9.4) except for the uppermost density interval (Table 1).

Phosphate (Fig. 5): as with nitrate, phosphorus regeneration is higher than the Redfield ratio equivalent calculated from AOU change. The enigmatic relationship between nitrate supply to the surface (Dietze et al., 2004) and subsurface oxygen consumption translated into nitrate regeneration de-

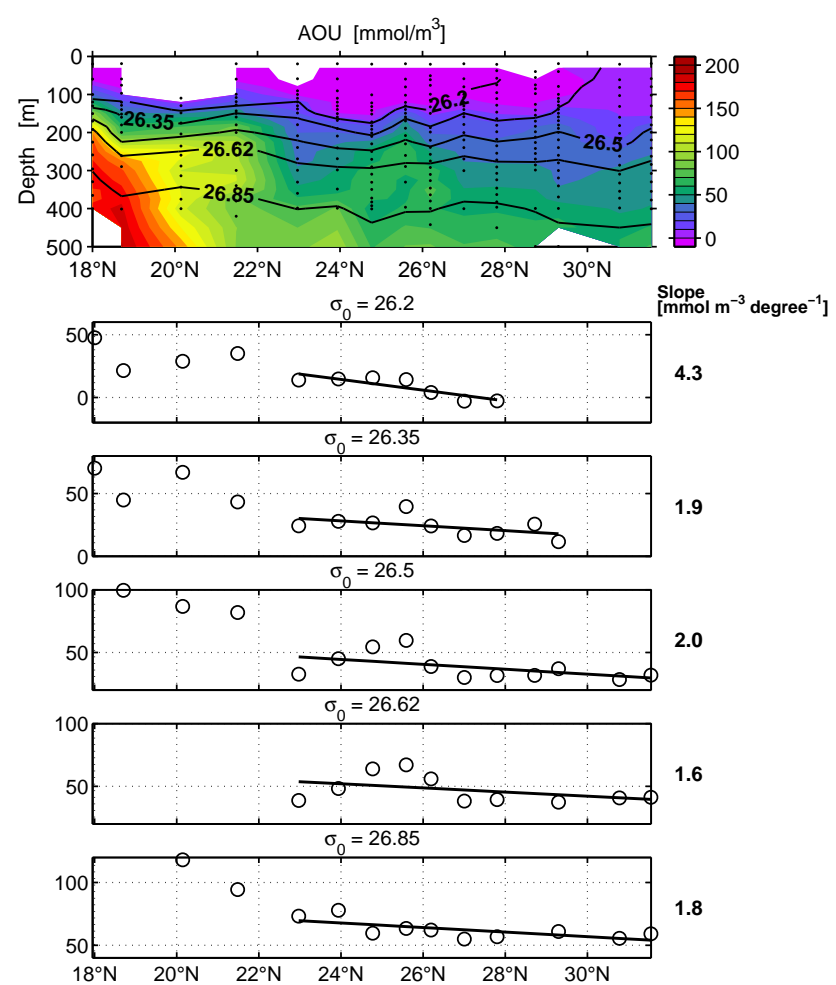

Fig. 2. Latitudinal section of apparent oxygen utilization (AOU, $\mathrm{mmol} \mathrm{O}_{2} \mathrm{~m}^{-3}$ ) along $30^{\circ} \mathrm{W}$ (2002 Section, upper panel) and latitudinal gradients of AOU along isopycnal intervals (lower panels). The data south of $22.9^{\circ} \mathrm{N}$ are not included in the regression for they are influenced by water of southern origin.

scribed in the introduction, therefore, should also be one of phosphate supply vs. oxygen consumption. Phosphorus regeneration in subsurface water should equally be far greater than diffusive phosphorus supply to the surface.

Excess nitrogen (Fig. 6): Any process adding nitrogen to the system but not phosphorus, or adding nutrients in a ratio wider than the Redfield N:P ratio, will tend to inflate the $\mathrm{N}: \mathrm{P}$ ratios above the Redfield ratio proportion. This can occur both in living organic matter (Karl et al., 1995) and its decomposition products, and was observed in our study area. 


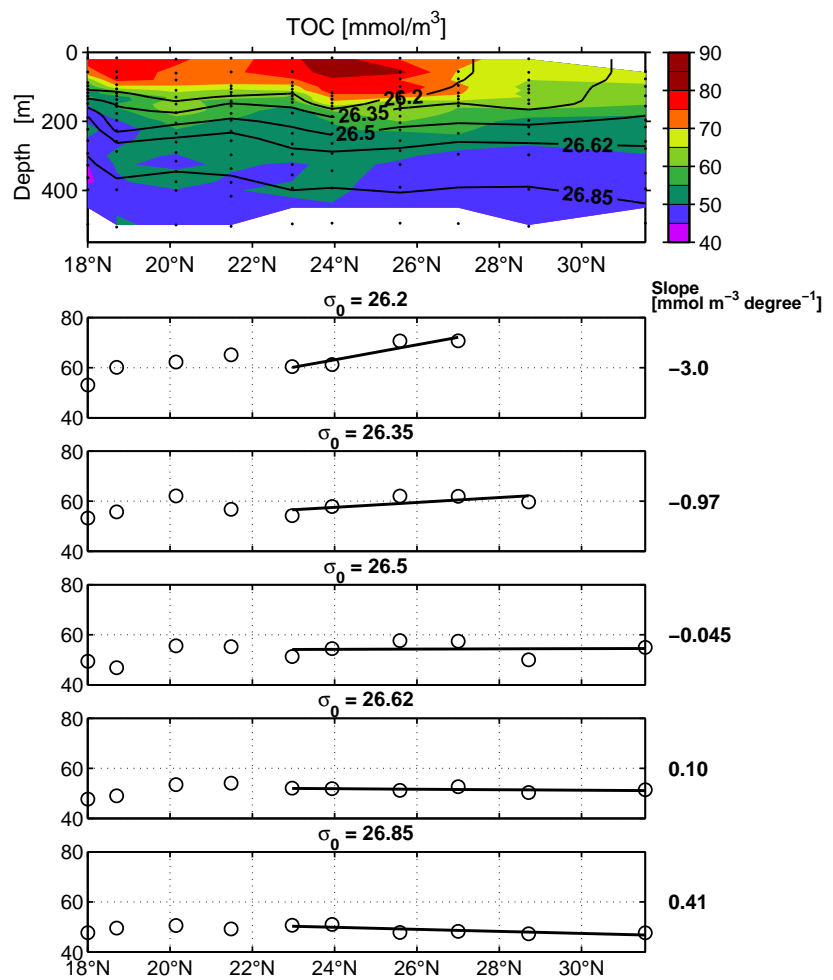

Fig. 3. Latitudinal section of total organic carbon (TOC, mmol $\mathrm{C} \mathrm{m}^{-3}$ ) along $30^{\circ} \mathrm{W}$ (2002 Section, upper panel) and latitudinal gradients of TOC along isopycnal intervals (lower panels). The data south of $22.9^{\circ} \mathrm{N}$ are not included in the regression for they are influenced by water of southern origin.

The average N:P ratio of bulk organic matter was 23 (compared with 16 of the Redfield ratio, Fig. 7), and the ratio with which $\mathrm{NO}_{3}$ and $\mathrm{PO}_{4}$ are supplied to surface water from below is also 23 (Dietze et al., 2004). Supposing excess subsurface nitrate to ultimately stem from the export and breakdown of organic matter enriched in $\mathrm{N}$ by $\mathrm{N}_{2}$ fixation, the dynamics of this term has been used to quantify the effect of nitrogen fixation (Michaels et al., 1996; Gruber and Sarmiento, 1997). We define excess nitrate as

DINxs $=\mathrm{NO}_{3}+\mathrm{NO}_{2}-16 * \mathrm{PO}_{4}$

(i.e. include $\mathrm{NO}_{2}$, but neglect ammonium which was unimportant.) The notation DINxs was introduced by Hansell et al. (2004a). DINxs is similar to the $\mathrm{N}^{*}$ parameter of Gruber and Sarmiento (1997), but lacks an offset and a scaling factor. A region of positive DINxs is observed in the oligotrophic centre of the studied transect between 150 and $400 \mathrm{~m}$ (Fig. 6). Comparing the gradients of DINxs with those of nitrate shows that between 11 and $38 \%$ of nitrate regeneration is excess nitrate depending on density layer.

TON: along with TOC there is organic nitrogen (TON), which is exported from the surface and decomposed in subsurface water. We cannot quantify this component with
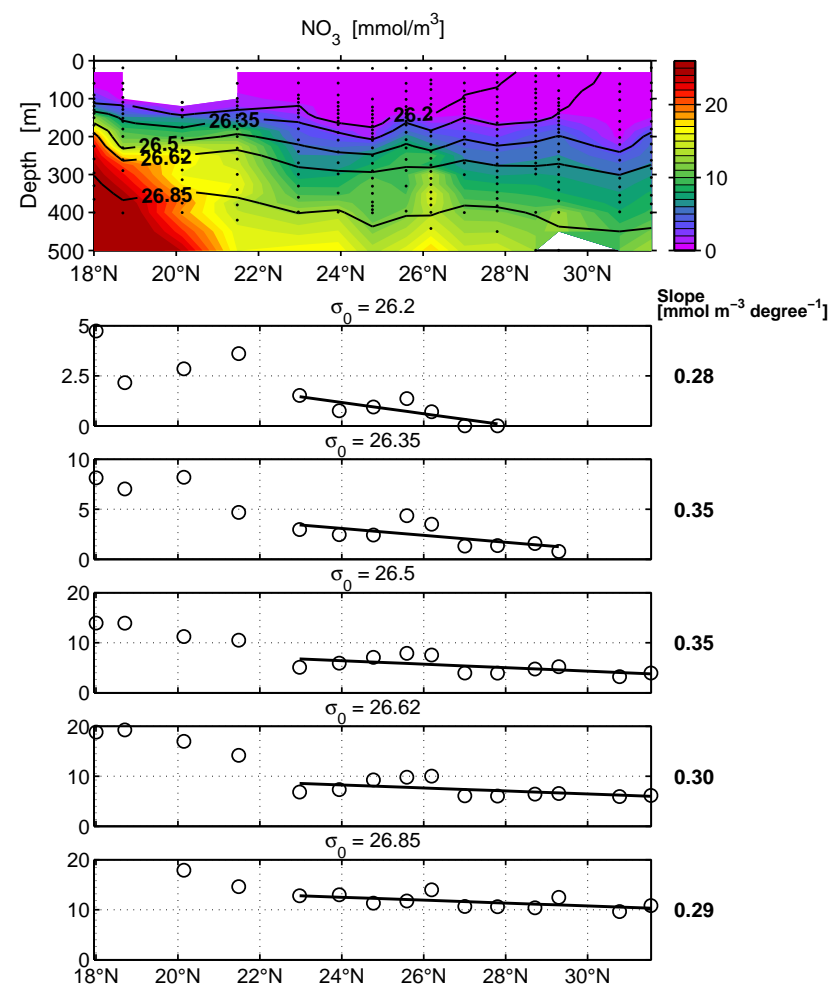

Fig. 4. Latitudinal section of nitrate (incl. nitrite, $\mathrm{mmol} \mathrm{NO}_{3} \mathrm{~m}^{-3}$ ) along $30^{\circ} \mathrm{W}$ (2002 Section, upper panel) and latitudinal gradients of nitrate along isopycnal intervals (lower panels). The data south of $22.9^{\circ} \mathrm{N}$ are not included in the regression for they are influenced by water of southern origin.

the same confidence as TOC since we lack reliable subsurface TON data. An estimate is possible assuming that the deep water concentration is equal to the lowest concentration measured by us and that this concentration is approached after subduction of the water and TON breakdown analogous to TOC breakdown. We define the amount of TON decomposed as the difference between this and the surface concentration. The lowest measured value in our dataset is $4.6 \mu \mathrm{mol} \mathrm{TON} \mathrm{dm}{ }^{-3}$, which is similar to the concentration measured by Bourbonnais et al. (2009) in surface water in the region of the Azores Front, to the north-east of our study area, and to deep water concentrations given by Vidal et al. (1999) and Hansell and Carlson (2001) for stations in the tropical and subtropical North Atlantic. An estimate of the probable amount of TON exported and broken down is possible for the two uppermost isopycnals only because only these two crop out within the transect studied, and it is only in these that surface TON concentrations are available.

The differences of surface TON against $4.6 \mu \mathrm{mol} \mathrm{TON} \mathrm{dm}{ }^{-3}$ between 23.9 and $28^{\circ} \mathrm{N}$ are $1.0 \mu \mathrm{mol} \mathrm{dm}^{-3}$ (for $\sigma_{0}=26.2$ ), and $1.34 \mu \mathrm{mol} \mathrm{dm}^{-3}$ between 23.9 and $30^{\circ} \mathrm{N}$ (for $\sigma_{0}=26.35$ ), respectively, or 0.24 and $0.22 \mu \mathrm{mol} \mathrm{TON} \mathrm{dm}{ }^{-3}$ per degree latitude. The C:N 


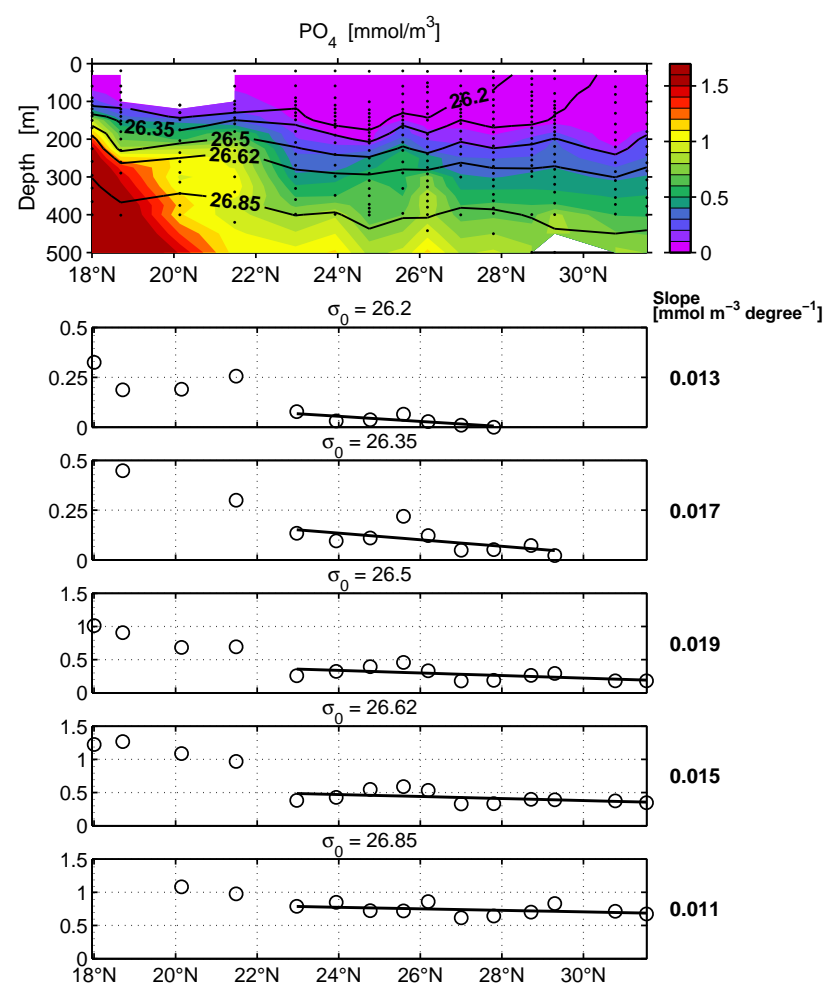

Fig. 5. Latitudinal section of phosphate $\left(\mathrm{mmol} \mathrm{PO}_{4} \mathrm{~m}^{-3}\right)$ along $30^{\circ} \mathrm{W}$ (2002 Section, upper panel) and latitudinal gradients of phosphate along isopycnal intervals (lower panels). The data south of $22.9^{\circ} \mathrm{N}$ are not included in the regression for they are influenced by water of southern origin.

ratios of dissolved organic matter export and subsurface degradation (delta $\mathrm{C}$ per degree latitude from Table 1) are $12.5\left(=3 / 0.24\right.$, for $\left.\sigma_{0}=26.2\right)$ and $4.4(=0.97 / 0.22$, for $\sigma_{0}=26.35$ ).

The associated phosphorus (total dissolved phosphorus, TOP) estimated in the same way as TON (Surface value: $0.15 \mu \mathrm{mol} \mathrm{TOP} \mathrm{dm}^{-3}$, deep water value: $0.10 \mu \mathrm{mol} \mathrm{TOP} \mathrm{dm}^{-3}$ ) shows that the proportion of TON and TOP change is above the Redfield ratio (20 and 27 compared with 16). Hence the export and decomposition of TON and TOP does probably contribute to excess nitrate build-up in subsurface water of the study area, by $20 \%$ for $\sigma_{0}=26.2$ and by $40 \%$ for $\sigma_{0}=26.2$. This result is in agreement with analyses of Landolfi (2005) and Landolfi et al. (2008), who emphasized the importance of dissolved organic nutrients for the build-up of DINxs in oligotrophic gyres.

\subsection{Surface water: DOC accumulation, DON consumption, and constancy of DOP}

Figure 8 gives the north-south distribution of the concentrations of TOC, TON, and TOP (total dissolved carbon, nitrogen and phosphorus, resp.) in surface water $(0-100 \mathrm{~m})$.

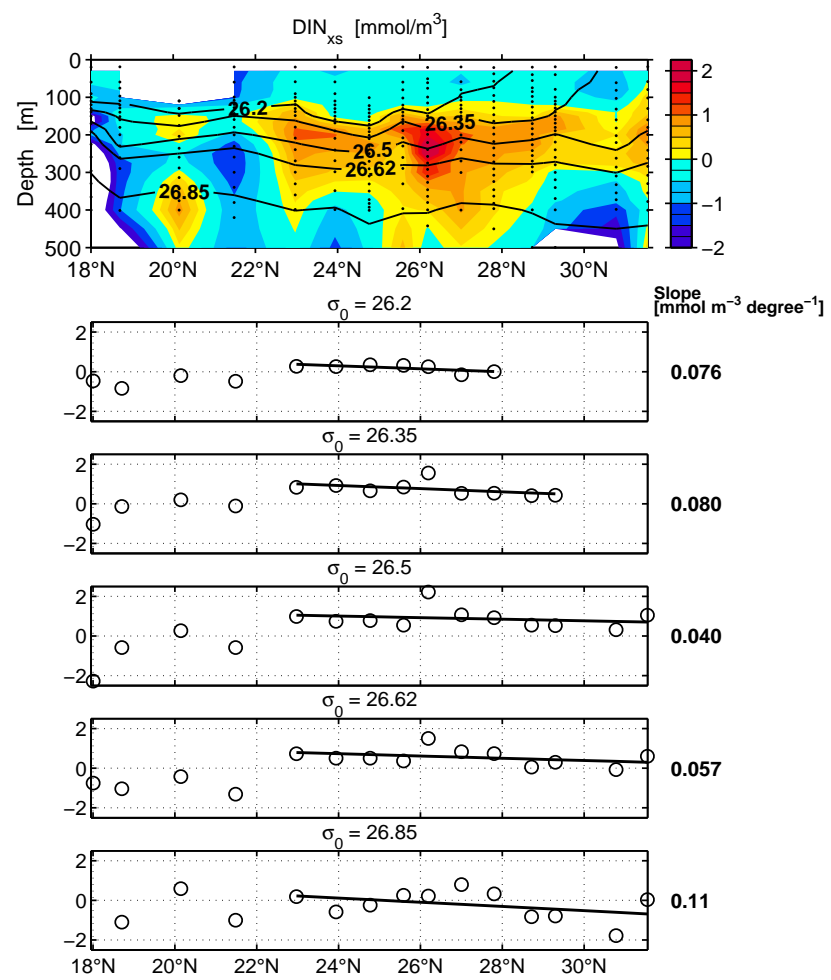

Fig. 6. Latitudinal section of excess nitrate (incl. nitrite, DINxs; mmol $\mathrm{N} \mathrm{m}^{-3}$ ) along $30^{\circ} \mathrm{W}$ (2002 Section, upper panel) and latitudinal gradients of excess nitrate along isopycnal intervals (lower panels). The data south of $22.9^{\circ} \mathrm{N}$ are not included in the regression for they are influenced by water of southern origin.

A rise in DOC and a drop of DON is observed in north-south direction while the concentration of TOP displays no trend.

The system of water movement in the suptropical gyre is not only characterized by subduction, but also by surface currents (Fig. 1a). There is a pronounced southward component (i.e. in the direction of our 2002 Section) in the near-surface flow in the Beta Triangle. The recompilation of the drogue data of Brügge (1995) yields a mean southward component of $3.9 \mathrm{~cm} \mathrm{~s}^{-1}$ at $100 \mathrm{~m}$ depth in the box bounded by 35 $25^{\circ} \mathrm{W}$ and $26-32^{\circ} \mathrm{N}$. The surface velocities measured continuously during our 2002 Cruise were $7.0 \mathrm{~cm} \mathrm{~s}^{-1}$ averaged vertically from $26-100 \mathrm{~m}$ depth and horizontally from 24 $32^{\circ} \mathrm{N}$ on $30^{\circ} \mathrm{W}$.

Taking these surface current velocities combined with the observed north-south surface gradients of TOC and TON yield their rates of production and consumption, respectively.

Surface $(0-100 \mathrm{~m}$ depth) TOC concentrations increased from $68.7 \mathrm{mmol} \mathrm{m}^{-3}$ at $31.5^{\circ} \mathrm{N}$ to $75.4 \mathrm{mmol} \mathrm{m}^{-3}$ at $22.9^{\circ} \mathrm{N}$ (Fig. 8). The two estimates of the surface current allow us to estimate rates of TOC build-up in surface water as 1.0 and $1.75 \mathrm{~mol} \mathrm{TOC} \mathrm{m}^{-2} \mathrm{a}^{-1}$, respectively. These are coarse order-of-magnitude estimates since the westward component of the current is ignored, as is any possible (e.g. seasonal) 


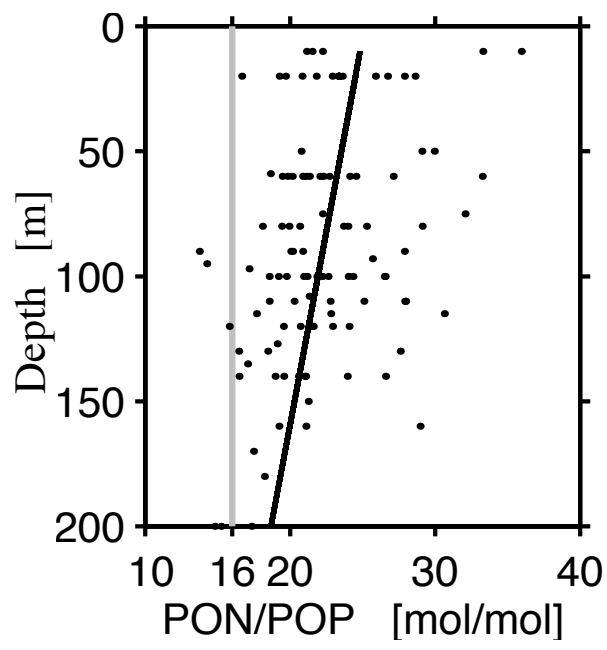

Fig. 7. N:P ratios in samples of particulate matter collected in the upper $200 \mathrm{~m}$ during March 2001 on a transect between $22.9^{\circ}$ and $32^{\circ} \mathrm{N}$.

variation in both current velocity and DOC gradient. It still reveals surface TOC accumulation as a potentially important component in the carbon cycle. There is only a small gradient in POC content along the transect, and its slope is opposite to that of the TOC gradient (data not shown). Hence, the observed TOC accumulation is caused by dissolved organic carbon DOC alone. Note that even the higher estimate of the rate of DOC build-up corresponds to $0.02 \mu \mathrm{mol} \mathrm{O}_{2}$ equivalents per litre and day only, which is well below the analytical precision of the Winkler technique of $\mathrm{O}_{2}$ determination (cf. Williams et al., 2004).

Surface TON concentration dropped from 6.1 to 5.2 $\mu$ mol $\mathrm{dm}^{-3}$ between 31.5 and $22.9^{\circ} \mathrm{N}$ while surface TOP (total organic phosphorus) was constant over the same distance at 0.15 , to rise to $0.33 \mu \mathrm{mol} \mathrm{dm}{ }^{-3}$ only further south (Fig. 8). With a mean surface current of $7.0(3.9) \mathrm{cm} \mathrm{s}^{-1}$ heading south the difference of $0.9 \mu \mathrm{mol} \mathrm{dm}{ }^{-3}$ corresponds to TON consumption along the transect of $0.23(0.13) \mathrm{mol} \mathrm{m}^{-2} \mathrm{a}^{-1}$ in the upper $100 \mathrm{~m}$.

\section{Discussion}

\subsection{Limitations and possibilities of our approach}

When planning the work described in this study, we intended to fit the measurements we made into an extended balance of carbon and nitrogen using the measured concentrations combined with times of reaction provided in the literature (Jenkins, 1982, 1987). This proved to be illusory, since this would have relied on a number of assumptions which showed not to apply. The state of the environment was found to be different during our study from that of Jenkins, showing that one precondition for establishing a representative annual budget

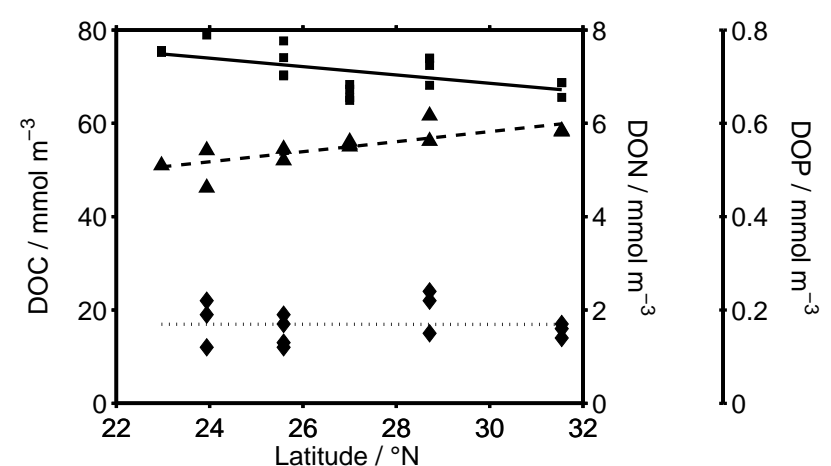

Fig. 8. Concentrations of dissolved organic carbon (squares), nitrogen (triangles) and phosphorus (diamonds) in surface water (0$100 \mathrm{~m}$ ) between $22.9^{\circ}$ and $32^{\circ} \mathrm{N}$ along the transect of Fig. 1.

from the distribution of properties during the limited time of a single cruise is not possible. Seasonal differences between the study of Jenkins $(1982,1987)$ and ours are evident. For example, isopycnal layers reaching the surface within our transect $\left(\sigma_{0}=26.2\right.$ and 26.35) during our study were well below the surface in Jenkins' studies - a seasonal effect between spring (our study) and autumn (data for Jenkins' studies were taken late October 1979, Jenkins, 1987). It is probably therefore, that the subduction and decomposition of DOC including its large effect on AOU which we observed in the upper two isopycnal surfaces, has been absent or less pronounced in his studies: our gradients of AOU with latitude are 4.3 to $1.8 \mathrm{mmol} \mathrm{m}^{-3}$ per degree latitude, from top to bottom (Table 1); Jenkins' (1987) AOU gradients, read from the geographical distribution along $30^{\circ} \mathrm{W}$ were, in the same latitudinal interval, $1-5 \mathrm{mmol} \mathrm{m}^{-3}$ per degree latitude, from top to bottom (Table 1).

Reasons for not providing vertical integrals of rates of reaction (prerequisite for a regional balance) are that we have no measure of the time component of the gradients we describe taken at the same time. Age distributions of water masses in the study area are given by Jenkins (1987) and Hansell et al. (2004a). A comparison shows that the respective rates of water transport differ considerably.

Also, our study concerns only the surface $100 \mathrm{~m}$ and a layer between ca. 140 and $500 \mathrm{~m}$. The work of Jenkins $(1982,1987)$ showed that about one third of the ongoing oxygen consumption was below $500 \mathrm{~m}$ where we did not collect samples. Thirdly, our north-south transect is not perfectly in the direction of the prevailing currents, and the condition that no mixing-in of alien water is not completely true; Jenkins (1987) estimates a maximum contribution of $10 \%$.

Finally, to construct a balance would mean to combine data representative of different time scales. The nearer to the surface, the shorter is the time which is represented in the transect studied by us. Jenkins (1987) gives 0.4 year in the $\sigma_{0}=26.2$ isopycnal (near-surface) and 1.9 years for 
$\sigma_{0}=26.85$ (the deepest isopycnal sampled by us), as read from the distributions of water age in Figs. 4-8 of Jenkins (1987). Hansell et al. (2004a) give less than a year for $\sigma_{0}=26$ and 3-4 years for $\sigma_{0}=26.5$, derived from analyses of CFC content for the same latitudinal range along $30^{\circ} \mathrm{W}$. Therefore, a possible seasonality of the gradients and currents would influence especially the near-surface results but would be levelled in deeper strata. Vertical integration would combine rates representative of different times. Also the surface rates which we report are representative only of the situation which we encountered during the cruise.

While these reservations are serious drawbacks to the construction of an annual balance, general conclusions concerning the importance of the processes studied can still be drawn.

The time elapsed since water left the surface mixed layer (i.e. water age) does not increase monotonically towards the south on a given isopycnal, and inputs into the respective layers cannot be expected to be constant. This shows in the deviations of our data from the linear trend of the regression lines. On spacial scales larger than eddy scales (which applies to our transects extending over more than $200 \mathrm{~km}$ ) it can be assumed with high certainty that water age is higher in the south than in the north. On average, age will increase towards the south, and to use linear trends of concentrations along isopycnals in north-south direction provides a means of averaging the data. Note that all conclusions drawn could be obtained as well by just comparing data at the northernmost station with those at $23^{\circ} \mathrm{N}$.

Whether our transect is exactly aligned with the current or not does not concern the validity of our conclusions since the outcrop locations of the two uppermost isopycnals (carriers of the bulk of the observed effects) are well within the oligotrophic gyre and should therefore be subducted with similar preformed values of nutrients and oxygen. None of the data points in Figs. 2-6 are from the mixed layer as was confirmed from profiles taken at each station (not shown here). Oxygen concentrations slightly above values typical of equilibrium with the atmosphere occur (as in Jenkins' 1987 study) in two data points (Fig. 2 on the 26.35 density level). This does not mean that the respective samples are from the mixed layer as other processes, both abiotic and biotic ones, such as solar radiation penetrating below the surface mixed layer (e.g. Dietze and Oschlies, 2005) or photosynthesis in the deep chlorophyll maximum are known to be potential drivers of oversaturation in waters below the surface mixed layer.

Where rates cannot be calculated by us for lack of age tracer measurements, their relative proportion is evident from the comparison of the gradients which they sustain in relation to the gradient of AOU. The comparison of states (rather than rates) still shows that our study is suited to address the questions raised by the work of Jenkins. AOU in subsurface water is of a similar magnitude (even larger) as the AOU which had been impossible to explain within the conventional concept. Despite the impossibility to provide a complete carbon- nitrogen-balance of the Beta Triangle region, our study still shows that there are important biotic transformations of carbon and nitrogen in the study area, which are not included in the conventional concept of production in the ocean. The processes are: the accumulation of DOC in surface water, its partial export to shallow depths and its breakdown there, and the net consumption of DON (but not DOP) in surface water in an amount likely to be responsible for subsurface DINxs.

A number of statements concerning the questions treated in the introduction of this study can be made.

\subsection{The oligotrophic ocean in the Beta Triangle region is autotrophic}

The notion of the subtropical oligotrophic areas of the ocean being heterotrophic has been developed from compilations of experimental data, namely the measurements of photosynthesis, respiration, or carbon demand calculated from the determinations of bacterial growth rates. In most publications advocating a heterotrophic oligotrophic ocean the substrate to support respiration in excess of autotrophic production is not mentioned.

Should this notion be true, a transport of organic matter into the oligotrophic gyres, and its consumption there, should be observed, i.e. the surface concentration should drop as water approaches the centre of the gyre. Our data show an increase rather than a decrease of organic matter in the direction of the current, i.e. organic matter is produced rather than consumed. This organic matter build-up in surface water shows it to be autotrophic unambiguously. To this organic-matter build-up any organic matter exported from surface water must be added as autotrophic components, i.e. exported dissolved and particulate matter, that is anything contributing to subsurface oxygen utilization.

The inclusion of dissolved organic matter production as well as its consumption in the shallow subsurface into the (oxygen-) carbon balance of the Beta Triangle region thus reveals the autotrophic state of its surface layer. There is lateral import of DOC at depth which is consumed there (heterotrophy), but this is in the subsurface and does not affect the trophic balance of the surface layer. Interestingly, the distant (autotrophic) source of this organic matter, i.e. the regions where the $\sigma_{0}=26.2$ and 26.35 isopycnal layers crop out, is at the northern boundary of the Beta Triangle and thus well within the oligotrophic ocean. The regional contribution of the subducted DOC therefore is also autotrophic with respect to surface water.

Viewing the heterotrophy/autotrophy problem from the angle of large-scale DOC transports Hansell et al. (2004b) evaluate the trophic state of the North Atlantic. Accounting for DOC transports over the boundaries of this basin they describe it as marginally heterotrophic as a whole, but explicitly not heterotrophic in its subtropical parts. 
We conclude that surface DOC distribution and dynamics has the potential to be the solution to the apparent heterotrophy of the oligotrophic ocean. The surface distribution of DOC has maxima in warm oligotrophic regions and minima in cold nutrient-rich ones (Abell et al., 2000; Hansell, 2002; Kähler et al., 1997; Kähler and Koeve, 2001). The pattern that surface DOC concentrations increase towards the centres of oligotrophy in the subtropics has been described several times and seems to be generally the case, while there is no description of a reverse distribution as would be necessary should DOC be consumed in the oligotrophic parts of the ocean.

\subsection{Carbon overconsumption by N-poor DOC forma- tion and export is important, but in surface water and shallow subsurface water only}

In the uppermost two isopycnal surfaces studied by us the breakdown of DOC explains about 70 resp. 50\% of oxygen consumption. While it is certainly important there, it cannot resolve the mismatch of the carbon (oxygen)-nitrogen balances, since its impact extends down to maximally $195 \mathrm{~m}$, while the bulk of oxygen consumption which is part of the historical discrepancy is deeper than that. About $90 \%$ of the oxygen consumption in the Beta Triangle region is occurring deeper than $200 \mathrm{~m}$ (Jenkins, 1987, his Table 3).

As far as surface water is concerned, the formation of DOC is the one process in the $\mathrm{C}$ balance which is of overriding importance. The increase of DOC towards the centre of oligotrophic subtropical gyres or, generally, along with rising surface temperature and depletion of nutrients has been described by a number of authors (Peltzer and Hayward, 1996; Abell et al., 2000; Kähler and Koeve, 2001; Hansell, 2002) and seems to be a general feature of warm, nutrient poor waters. Also its shallow export in these systems is recognized as a general feature of subtropical gyres (Abell et al., 2000; Doval and Hansell, 2000; Hansell, 2002).

Both components (accumulating and exported dissolved organic matter) have $\mathrm{C}: \mathrm{N}$ ratios deviating from Redfield $\mathrm{C}: \mathrm{N}$ ratio of 6.6. The accumulating DOC in surface water is accompanied by decreasing DON concentrations, hence it causes carbon overconsumption. Since in the surface, the southward DOC increase is accompanied by a decrease of DON, the C:N ratios of the accumulated and exportable/exported dissolved organic matter is continuously increasing in this direction. The dissolved organic matter subducted and broken down in the shallow subsurface has an estimated $\mathrm{C}: \mathrm{N}$ ratio of 12.5 in the uppermost isopycnal level $\left(\sigma_{0}=26.2\right)$, but one of 4.4 in the next depth level $\left(\sigma_{0}=26.35\right)$. Here dissolved organic matter reflects carbon "underconsumption" and is responsible for the low $\mathrm{O}_{2}: \mathrm{NO}_{3}$ ratio (Table 1). The composition of dissolved organic matter is not constrained by the necessity to function as a living organism, which is the biological basis of the Redfield ratio (Kähler and Koeve, 2001). Deviations in all direction seem possible. While carbon overconsumption has been ascribed to DOC buildup or export (Kähler and Koeve, 2001; Emerson and Hayward, 1995), the contribution of dissolved organic matter on the $\sigma_{0}=26.35$ isopycnal is an example of the reverse. In current applications of traditional concepts of ocean productivity which equate nitrate supply, new, and export production the build-up of dissolved organic matter with variable $\mathrm{C}: \mathrm{N}$ ratios and its partial export are not included. This, we think, is not for ignorance of its potential importance, but for lack of understanding the rules which govern its production and consumption, its accumulation and export, and the elemental ratios of these.

The dynamics and distribution of DOC make it necessary to reassess the notion of the oligotrophic regions of the oceans having a heterotrophic surface layer by including DOC in the carbon balance. Recent studies of the "metabolic balance of the ocean" (Lopez-Urrutia et al., 2006), or the role of eddies in $\mathrm{C}$ and $\mathrm{N}$ dynamics of the oligotrophic subtropical North Atlantic (Mouriño-Carballido, 2009) for example do not consider dissolved organic matter at all. Also its consideration as a minor constant percentage of primary production (Rivkin and Legendre, 2001) will certainly not do where DOC is a major component of the carbon cycle.

\subsection{Nitrogen fixation may be important, but DINxs is a poor proxy}

The DINxs increase can be attributed to $\mathrm{N}_{2}$ fixation only with reservations. Obviously, any nutrient additions of large N:P proportion - not $\mathrm{N}_{2}$ fixation alone - would tend to produce a positive DINxs signature in the subsurface. Our data allow to single out DON utilisation, for in our transect we observe the net utilization of total organic nitrogen (TON) in surface water at an estimated rate which is two to four times higher than nitrate supply in the area. We have no information on how this DON has originally been formed. Hansell et al. (2007) suggested $\mathrm{N}_{2}$ fixation to be less important than suggested by taking DINxs development to provide $\mathrm{N}_{2}$ fixation rates. Much of the DINxs development which they describe can be attributed to DON utilization, especially in a region in which the Beta Triangle lies. However, the DON gradient must itself have been built up and maintained by a process adding nitrogen to the system, and this may well be $\mathrm{N}_{2}$ fixation. Another possibility is the deposition of material high in N:P from the air, which Hansell et al. (2007) also make responsible for much of the observed DINxs in the North Atlantic, but this is far north-west of our study area.

Global surveys of the depositions of nitrogen and phosphorus (Dentener et al., 2006; Mahowald et al., 2008) show that in our study area $\mathrm{N}$ deposition is at a minimum and $\mathrm{P}$ deposition at a maximum. Calculating the molar N:P ratio for the ranges of $\mathrm{N}$ and $\mathrm{P}$ deposition, resp. provided in the global maps in these publications shows that even here there is an excess of $\mathrm{N}(\mathrm{N}: \mathrm{P}=55)$. Compared with other sources of $\mathrm{N}$ and $\mathrm{P}$, however, deposition from the air is very small and 
thus not able to influence bulk N:P ratios in the study area. The estimated atmospheric $\mathrm{P}$ deposition would sustain only $1.6 \%$ of the production estimated by Jenkins (1987; 0.09 of $5.7 \mathrm{mmol} \mathrm{C} \mathrm{m}^{-2} \mathrm{a}^{-1}$, when applying the Redfield C:P ratio).

In a similar approach using basin-wide excess nitrate combined with CFC water age the eastern part of the subtropical gyre (i.e. our study area) turned out a prominent source of extra (fixed?) nitrogen for the North Atlantic (Hansell et al., 2002). More direct and indirect evidence of $\mathrm{N}_{2}$ fixation in the study area collected during our cruises, both from ${ }^{15} \mathrm{~N}_{2}$ uptake experiments, in situ $\mathrm{N}$-isotope analyses, and genomic studies will be given in a forthcoming publication (Kähler et al., 2010). Our analysis and that of Hansell et al. (2002) contrast with former estimates which assign nitrogen fixing activity to more western locations in the Atlantic (Michaels et al., 1996; Gruber and Sarmiento, 1997). Extensive measurements conducted there (Orcutt et al., 2001) did not reach the level suggested by Gruber and Sarmiento (1997) though. Low nitrogen fixation in the west is also evidenced by the lack of seasonal variation in organic nitrogen stocks at the Bermuda Time Series Station (Hansell and Carlson, 2001).

\subsection{It is not only $\mathrm{N}$ which is " $\mathrm{missing}$ " but also $\mathrm{P}$}

The historical mismatch was described as one between oxygen consumption (and hence carbon export production) and nitrogen supply. Our data show that with phosphorus the situation is similar. The diffusive supply of phosphorus (accounting also for double diffusion) is $0.004 \mathrm{~mol} \mathrm{PO}_{4} \mathrm{~m}^{-2} \mathrm{a}^{-1}$ (Dietze et al., 2004). Phosphorus demand for a production consuming $5.7 \mathrm{~mol} \mathrm{O}_{2} \mathrm{~m}^{-2} \mathrm{a}^{-1}$ (Jenkins, 1982) after being exported to subsurface water is $0.04 \mathrm{~mol} \mathrm{PO}_{4} \mathrm{~m}^{-2} \mathrm{a}^{-1}$, that is 10 times the diffusive supply. It is therefore not only the supply of nitrogen to the surface which is insufficient to explain a new production necessary to support export of a magnitude large enough to sustain subsurface oxygen consumption, but equally the supply of phosphorus. High rates of nitrogen fixation, DON utilization, or excess $\mathrm{N}$ deposition from the air (Hansell et al., 2007) can supply additional nitrogen, but obviously not additional phosphorus.

It is an external source of phosphorus which must be searched for. Not many possibilities exist. Dissolved organic phosphorus is no option in the situation we describe since its concentrations do not vary along the direction of the current. This may be different though, for example during seasons other than spring. Abell et al. (2000) describe net DOP consumption along a transect in the subtropical gyre of the North Pacific, which shows that constancy of surface DOP as observed by us cannot be assumed to be generally the case. Data on DOP in, or in the vicinity of, our study area (Mahaffey et al., 2004) are too scarce to recognize regional or seasonal patterns.
The necessity or possibility of an external phosphorus input has interesting bearings on the adequateness of parameters like DINxs (this study, Hansell et al., 2002) and also $\mathrm{N}^{*}$ of Gruber and Sarmiento (1997), and excess N of Michaels et al. (1996) as indicators of nitrogen fixation. Since by such parameters only that nitrogen is accounted for which is in surplus of that in the Redfield ratio with phosphorus, these parameters would not account for any nitrogen fixation based on the addition of extra phosphorus. While high N:P ratios have been observed in organisms fixing nitrogen and in nitrogen fixing communities this cannot be considered a necessary prerequisite of nitrogen fixation. It is, however, a necessary prerequisite for positive DINxs development. Phosphorus additions may support $\mathrm{N}_{2}$ fixation in which organic matter in the Redfield ratio is produced. This $\mathrm{N}_{2}$ fixation would not be detectable with any excess $\mathrm{N}$ parameter, however.

\section{Conclusions}

Establishing a long-term complete balance of oxygen, carbon, and nutrients showed to be difficult (impossible with the data in the literature and ours) for the transect we occupied in the Beta Triangle. The historical mismatch of $\mathrm{N}$ supply and oxygen consumption, and the resulting gaps of nitrogen and carbon are of magnitudes though, to justify doubts in the completeness of conventional approaches to such a balance, in which biotic production and consumption are reduced to particulate matter and nutrients to nitrate.

Certain processes, or their effects, which we quantified showed to be of magnitudes large enough to contribute significantly to filling gaps in the balances. The net production and partial export and breakdown of DOC is large and shows the study area to be autotrophic. However, DOC dynamics is confined to surface water and shallow depths only, and depth levels where the historical gaps showed are not affected. The utilization of nitrogen from $\mathrm{N}_{2}$ fixation, DON utilization, or the (small) introduction of excess $\mathrm{N}$ from the air combine to explain existing excess nitrogen in subsurface water and contribute to close the nitrogen gap, but not the equally serious phosphorus gap.

Acknowledgements. Captain and crew of FS Poseidon supported our work on two cruises. Nutrients and POM were measured by P. Fritsche and K. Nachtigall. This work was funded by an Interdisciplinary Working Group at the IFM-GEOMAR (P. K. and H. D.) and by the CAU Excellence Cluster "The Future Ocean" (P. K. and W. K.). This study profited from discussions with B. Mouriño-Carballido and A. Landolfi. Thanks also to two anonymous reviewers for their helpful comments.

Edited by: E. Boss 


\section{References}

Abell, J., Emerson, S., and Renaud, P.: Distributions of TOP, TON and TOC in the North Pacific subtropical gyre: Implications for nutrient supply in the surface ocean and remineralization in the upper thermocline, J. Mar. Res., 58, 203-222, 2000.

Anderson, L. A.: On the hydrogen and oxygen content of marine phytoplankton, Deep-Sea Res. I, 42, 1675-1680, 1995.

Anderson, L. A. and Sarmiento, J. L.: Redfield ratios of remineralization determined by nutrient data-analysis, Global Biogeochem. Cy., 8, 65-80, 1994.

Bourbonnais, A., Lehmann, M. F., Waniek, J. J., and SchulzBull, D. E.: Nitrate isotope anomalies reflect $\mathrm{N}_{2}$ fixation in the Azores Front region (subtropical E Atlantic), J. Geophys. Res., 114, C03003, doi:10.1029/2007JC004617, 2009.

Brügge, B.: Near-surface mean circulation and kinetic-energy in the central North-Atlantic from drifter data, J. Geophys. Res.Oceans, 100, 20543-20554, 1995.

Dentener, F., Drevet, J., Lamarque, J. F., Bey, I., Eickhout, B., Fiore, A. M., Hauglustaine, D., Horowitz, L. W., Krol, M., Kulshrestha, U. C., Lawrence, M., Galy-Lacaux, C., Rast, S., Shindell, D., Stevenson, D., Van Noije, T., Atherton, C., Bell, N., Bergman, D., Butler, T., Cofala, J., Collins, B., Doherty, R., Ellingsen, K., Galloway, J., Gauss, M., Montanaro, V., Muller, J. F., Pitari, G., Rodriguez, J., Sanderson, M., Solmon, F., Strahan, S., Schultz, M., Sudo, K., Szopa, S., and Wild, O.: Nitrogen and sulfur deposition on regional and global scales: A multimodel evaluation, Global Biogeochem. Cy., 20, Gb4003, doi:10.1029/2005gb002672, 2006.

Dietze, H. and Oschlies, A.: Modeling abiotic production of apparent oxygen utilisation in the oligotrophic subtropical North Atlantic, Ocean Dynam., 55, 30-33, doi:10.1007/s10236-0050109-z, 2005.

Dietze, H., Oschlies, A., and Kähler, P.: Internal-wave-induced and double-diffusive nutrient fluxes to the nutrient-consuming surface layer in the oligotrophic subtropical North Atlantic, Ocean Dynam., 54, 1-7, doi:10.1007/s10236-003-0060-9, 2004.

Doval, M. and Hansell, D. A.: Organic carbon and apparent oxygen utilization in the western South Pacific and central Indian Oceans, Mar. Chem., 68, 249-264, 2000.

Doval, M. D., Álvarez-Salgado, X. A., and Pérez., F. F.: Organic matter distributions in the eastern North Atlantic-Azores front region, J. Marine Syst., 30, 33-49, 2001.

Duarte, C. M., Agusti, S., P. A. del Giorgio., and Cole, J. J.: Regional carbon imbalances in the oceans, Science, 284, 173-174, 1999.

Dugdale, R. C. and Goering, J. J.: Uptake of new and regenerated forms of nitrogen in primary productivity, Limnol. Oceanogr., 12, 196-206, 1967.

Eden, C. and Dietze, H.: Effects of mesoscale eddy/wind interactions on biological new production and eddy kinetic energy, J. Geophys. Res., 114, C05023, doi:10.1029/2008JC005129, 2009.

Emerson, S. and Hayward, T. L.: Chemical tracers of biological processes in shallow waters of the North Pacific: Preformed nitrate distributions, J. Mar. Res., 53, 499-513, 1995.

Ehrhardt, M. G. and Koeve, W.: Determination of Particulate Organic Carbon and Nitrogen, in: Methods of Seawater Analysis, 3rd edn, edited by: Grasshoff, K., Kremling, K., and Ehrhardt, M. G., Wiley-VCH, Weinheim, 437-444, 1999.
Eppley, R. W. and Peterson, B. J.: Particulate organic matter flux and planktonic new production in the deep ocean, Nature, 282, 677-682, 1979.

Gaarder, T. and Gran, H. H.: Investigations of the production of plankton in the Oslo Fjord, Rapp. et Proc.-Verb., Cons. Internat. Explor. Mer., 42, 1-48, 1927.

del Giorgio, P. A., Cole, J. J., and Cimbleris, A.: Respiration rates in bacteria exceed phytoplankton production in unproductive aquatic systems, Nature, 385, 148-151, 1997.

del Giorgio, P. A. and Duarte, C. M.: Respiration in the open ocean, Nature, 420, 379-384, 2002.

Grasshoff, K., Ehrhardt, M., and Kremling, K.: Methods of Seawater Analysis, Verlag Chemie, Weinheim, 419 pp., 1983.

Gruber, N. and Sarmiento, J. L.: Global patterns of marine nitrogen fixation and denitrification, Global Biogeochem. Cy., 11, 235266, 1997.

Hamilton, J. M., Lewis, M. R., and Ruddick, B. R.: Vertical fluxes of nitrate associated with salt-fingers in the worlds oceans, J. Geophys. Res.-Oceans, 94, 2137-2145, 1989.

Hansell, D. A.: DOC in the global ocean carbon cycle, in: Biogeochemistry of Marine Dissolved Organic Matter, edited by: Hansell, D. A. and Carlson, C. A., Academic Press, Amsterdam, 685-716, 2002.

Hansell, D. A. and Carlson, C. A.: Biogeochemistry of total organic carbon and nitrogen in the Sargasso Sea: Control by convective overturn, Deep Sea Res. II, 44, 1649-1667, 2001.

Hansell, D. A., Bates, N. R., and Olson, D. B.: Excess nitrate and nitrogen fixation in the North Atlantic Ocean, Mar. Chem., 84, 243-265, doi:10.1016/j.marchem.2003.08.004, 2004a.

Hansell, D. A., Ducklow, H. W., Macdonald, A. M., and Baringer, M. O.: Metabolic poise in the North Atlantic Ocean diagnosed from organic matter transports, Limnol. Oceanogr., 49, 1084-1094, 2004b.

Hansell, D. A., Olson, D. B., Dentener, F., and Zamora, L. M.: Assessment of excess nitrate development in the subtropical North Atlantic, Mar. Chem., 106, 562-579, doi:10.1016/j.marchem.2007.06.005, 2007.

Jenkins, W. J.: Oxygen utilization rates in North Atlantic subtropical gyre and primary production in oligotrophic systems, Nature, 300, 246-248, 1982.

Jenkins, W. J.: ${ }^{3} \mathrm{H}$ and ${ }^{3} \mathrm{He}$ in the Beta Triangle: Observations of gyre ventilation and oxygen utilization rates, J. Phys. Oceanogr., 27, 763-783, 1987.

Jenkins, W. J. and Wallace, D. W. R.: Tracer Based Inferences of New Primary Production in the Sea, in: Primary Productivity and Biogeochemical Cycles in the Sea, edited by: Falkowski, P. G. and Woodhead, A. D., Plenum Press, New York, 299-316, 1992.

Karl, D. M., Letelier, R., Hebel, D., Tupas, L., Dore, J., Christian, J., and Winn, C.: Ecosystem changes in the North-Pacific subtropical gyre attributed to the 1991-92 El-Nino, Nature, 373, 230234, 1995.

Karl, D. M., Laws, E. A., Morris, P., Williams, P. J. L., and Emerson, S.: Global carbon cycle - Metabolic balance of the open sea, Nature, 426, 32-32, doi:10.1038/426032a, 2003.

Kähler, P., Bjørnsen, P. K., Lochte, K., and Antia, A.: Dissolved organic matter and its utilization by bacteria during spring in the Southern Ocean, Deep-Sea Res. II, 44, 341-353, 1997.

Kähler, P. and Koeve, W.: Dissolved organic matter in the ocean: Can its C:N ratio explain carbon overconsumption?, Deep-Sea 
Res. I, 48, 49-62, 2001.

Kähler, P., Oschlies, A., Sandow, M., et al.: High rates of $\mathrm{N}_{2}$ fixation in the eastern subtropical North Atlantic, Geophys. Res. Lett., in preparation, 2010.

Körtzinger, A., Hedges, J. I., and Quay, P. D.: Redfield ratios revisited: Removing the biasing effect of anthropogenic $\mathrm{CO}_{2}$, Limnol. Oceanogr., 46, 964-970, 2001.

Koeve, W.: Spring bloom carbon to nitrogen ratio of net community production in the temperate N. Atlantic, Deep-Sea Res. I, 51, 1579-1600, 2004.

Koeve, W.: Magnitude of excess carbon sequestration into the deep ocean and the possible role of TEP, Mar. Ecol. Prog. Ser., 291, 53-64, 2005.

Körzinger, A., Koeve, W., Kähler, P., and Mintrop, L.: C:N ratios in the mixed layer during the productive season in the northeast Atlantic Ocean, Deep-Sea Res. I, 48, 661-688, 2001.

Landolfi, A.: The importance of dissolved organic nutrients in the biogeochemistry of oligotrophic gyres, $\mathrm{PhD}$ thesis, National Oceanography Centre, University of Southampton, Southampton, 2005.

Landolfi, A., Oschlies, A., and Sanders, R.: Organic nutrients and excess nitrogen in the North Atlantic subtropical gyre, Biogeosciences, 5, 1199-1213, 2008, http://www.biogeosciences.net/5/1199/2008/.

Ledwell, J. R., McGillicuddy Jr., D. J., and Anderson, L. A.: Nutrient flux into an intense deep chlorophyll layer in a mode water eddy, Deep-Sea Res. II, 55, 1139-1160, 2008.

Lewis, M. R., Harrison, W. G., Oakey, N. S., Herbert, D., and Platt, T.: Vertical nitrate fluxes in the oligotrophic ocean, Science, 234, 870-873, 1986.

Lipschultz, F., Bates, N. R., Carlson, C. A., and Hansell, D. A.: New production in the Sargasso Sea: History and current status, Global Biogeochem. Cy., 16, 1-17, 2002.

Lopez-Urrutia, A., San Martin, E., Harris, R. P., and Irigoien, X.: Scaling the metabolic balance of the oceans, P. Natl. Acad. Sci. USA, 103, 8739-8744, doi:10.1073/pnas.0601137103, 2006.

Mahaffey, C., Williams, R. G., Wolff, G. A., and Anderson, W. T.: Physical supply of nitrogen to phytoplankton in the Atlantic Ocean, Global Biogeochem. Cy., 18, GB1034, doi:10.1029/2003GB002129, 2004.

Mahowald, N., Jickells, T. D., Baker, A. R., Artaxo, P., BenitezNelson, C. R., Bergametti, G., Bond, T. C., Chen, Y., Cohen, D. D., Herut, B., Kubilay, N., Losno, R., Luo, C., Maenhaut, W., McGee, K. A., Okin, G. S., Siefert, R. L., and Tsukuda, S.: Global distribution of atmospheric phosphorus sources, concentrations and deposition rates, and anthropogenic impacts, Global Biogeochem. Cy., 22, GB4026, doi:10.1029/2008gb003240, 2008.

Mann, K. H. and Lazier, J. R. N.: Primary production in the subtropical gyres, Chap. 8.5.1, in: Dynamics of Marine Ecosystems, edited by: Mann, K. H. and Lazier, J. R. N., Blackwell, Boston, 332-336, 1991.

McGillicuddy, Jr., D. J., Robinson, A. R., Siegel, D. A., Jannasch, H. W., Johnson, R., Dickey, T. D., McNeil, J., Michaels, A. F., and Knap, A. H.: Influence of mesoscale eddies on new production in the Sargasso Sea, Nature, 394, 263-266, 1998.

McGillicuddy Jr., D. J., Anderson, L. A., Bates, N. R., et al.: Eddy/wind interactions stimulate extraordi- nary mid-ocean plankton blooms, Science, 316, 1021, doi:10.1126/science.1136256, 2007.

Michaels, A. F., Bates, N. R., Buesseler, K. O., Carlson, C. A., and Knap, K. A.: Carbon system imbalances in the Sargasso Sea, Nature, 372, 537-540, 1994.

Michaels, A. F., Olson, D., Sarmiento, J. L., Ammerman, J. W., Fanning, K., Jahnke, R., Knap, A. H., Lipschultz, F., and Prospero, J. M.: Inputs, losses and transformations of nitrogen and phosphorus in the pelagic North Atlantic Ocean, Biogeochemistry, 35, 181-226, 1996.

Minster, J. F. and Boulahdid, M.: Redfield ratios along isopycnal surfaces - a complementary study, Deep-Sea Res., 34, 19812003, 1987.

Mouriño-Carballido, B. and Neuer, S.: Regional differences in the role of eddy pumping in the North Atlantic Subtropical Gyre - historical conundrums revisited, Oceanography, 21, 52-61, 2008.

Mouriño-Carballido, B.: Eddy-driven pulses of respiration in the Sargasso Sea, Deep-Sea Res. I, 56, 1242-1250, 2009.

Orcutt, K. M., Lipschultz, F., Gundersen, K., Arimoto, R. Michaels, A. F., Knap, A. H., and Gallon, J. R.: A seasonal study of the significance of $\mathrm{N}_{2}$ fixation by Trichodesmium spp. at the Bermuda Atlantic Time-series Study (BATS) site, Deep-Sea Res. II, 48, 1583-1608, 2001.

Oschlies, A.: Nutrient supply to the surface waters of the North Atlantic - A model study, J. Geophys. Res., 107, 3046, doi:10.1029/2000JC000275, 2002a.

Oschlies, A.: Can eddies make ocean deserts bloom? Global Biogeochem. Cy., 16, 1106, doi:10.1029/2001GB001830, 2002b.

Oschlies, A. and Kähler, P.: Biotic contribution to air-sea fluxes of $\mathrm{CO}_{2}$ and $\mathrm{O}_{2}$ and its relation to new production, export production, and net community production, Global Biogeochem. Cy., 18, GB1015, doi:10.1029/2003GB002094, 2004.

Parsons, T. R., Maita, Y., and Lalli, C. M.: A Manual of Chemical and Biological Methods for Sea-Water Analysis, Pergamon Press, Oxford, 1984.

Peltzer, E. T. and Hayward, N. A.: Spatial and temporal variability of total organic carbon along 140 degrees $\mathrm{W}$ in the equatorial Pacific Ocean in 1992, Deep-Sea Res. II, 43, 1155-1180, 1996.

Redfield, A. C, Ketchum, B. H., and Richards, F. A.: The influence of organisms on the composition of seawater, in: The Sea, Vol. 2, edited by: Hill, M. N., Interscience Publ., New York, 26-77, 1963.

Riser, S. C. and Johnson, K. S.: Net production of oxygen in the subtropical ocean, Nature, 451, 323-325, doi:10.1038/nature06441, 2008.

Rivkin, R. B. and Legendre, L.: Biogenic carbon cycling in the upper ocean: Effects of microbial respiration, Science, 291, 23982400, 2001.

Sambrotto, R. N., Savidge, G., Robinson, C., Boyd, P., Takahashi, T., Karl, D. M., Langdon, C., Chipman, D., Marra, J., and Codispoti, L.: Elevated consumption of carbon relative to nitrogen in the surface ocean, Nature, 363, 248-250, 1993.

Sarmiento, J. L. and Gruber, N.: Ocean Biogeochemical Dynamics, Princeton University Press, Princeton, 2006.

Serret, P., Robinson, C., Fernandez, E., Teira, E., and Tilstone, G.: Latitudinal variation of the balance between plankton photosynthesis and respiration in the eastern North Atlantic, Limnol. Oceanogr., 46, 1642-1652, 2001. 
Serret, P., Robinson, C., Fernández, E., Teira, E., Tilstone, G., and Pérez, V.: Predicting plankton net community production in the Atlantic Ocean, Deep Sea Res. II, 56, 941-953, 2009.

Steemann-Nielsen, E.: The use of radioactive carbon (14C) for measuring organic production in the sea, J. Cons. Perm. Int. Explor. Mer, 18, 117-140, 1952.

Takahashi, T., Broecker, W. S., and Langer, S.: Redfield ratio based on chemical data from isopycnal surfaces, J. Geophys. Res.Oceans, 90, 6907-6924, 1985.

Toggweiler, J. R.: Carbon overconsumption, Nature, 363, 210-211, 1993.
Vidal, M., Duarte, C. M., and Agusti, S.: Dissolved organic nitrogen and phosphorus pools and fluxes in the central Atlantic Ocean, Limnol. Oceanogr., 44, 106-115, 1999.

Williams, P. J. LeB.: On the definition of plankton production terms, ICES Mar. Sci. Symp., 197, 9-19, 1993.

Williams, P. J. LeB.: The balance of plankton respiration and photosynthesis in the open oceans, Nature, 394, 55-57, 1998.

Williams, P. J. LeB., Morris, P. J., and Karl, D. M.: Net community production and metabolic balance at the oligotrophic ocean site, Station ALOHA, Deep-Sea Res. I, 51, 1563-1578, 2004. 